\title{
Nutrient and energy conversion of grass-fed dairy and suckler beef cattle kept indoors and on high altitude pasture
}

\author{
Beda L. Estermann, Hans-Rudolf WetTstein, Franz SutTeR, \\ Michael KREUZER* \\ Group of Animal Nutrition, Institute of Animal Sciences, \\ Swiss Federal Institute of Technology (ETH), ETH centre/LFW, 8092 Zurich, Switzerland
}

(Received 17 April 2001; accepted 27 November 2001)

\begin{abstract}
In two experiments, system differences were determined between dairy cows (18-20 kg milk $\cdot \mathrm{d}^{-1}$ ) and suckler beef (cows with calves; $1.1-1.2 \mathrm{~kg}$ weight gain $\cdot \mathrm{d}^{-1}$ ) exclusively fed on grass. This included measurements of dry matter intake (DMI) and nitrogen $(\mathrm{N})$ turnover on an alpine pasture ( $n$ by group $=5 ; 2000 \mathrm{~m}$ a.s.l.; experiment $\mathrm{I})$, and of DMI, $\mathrm{N}$ and energy turnover in a lowland cowshed equipped with respiration chambers ( $n$ by group $=6 ; 400 \mathrm{~m}$ a.s.l.; experiment II). Within experiment II a high accuracy of slow-release alkane capsules for intake estimation was confirmed for grass-only diets because the difference between known intake and the prediction made using the $\mathrm{C}_{31}: \mathrm{C}_{32}$ alkane ratio was only $0.19 \mathrm{~kg} \cdot \mathrm{d}^{-1}(1 \%)$. Estimates were best with early-morning faeces samples. In experiment I grass DMI and $\mathrm{N}$ intake were equal in dairy cows and suckler beef with 16 and $0.30 \mathrm{~kg} \cdot \mathrm{d}^{-1}$, respectively. System N retention was higher in dairy cows with $25.7 \%$ of $\mathrm{N}$ intake vs. $9.2 \%$ in suckler beef. In experiment II, DMI of individual cows was equal in both systems $\left(16 \mathrm{~kg} \cdot \mathrm{d}^{-1}\right)$, whereas total system DMI (cows and calves) was higher in suckler beef $\left(20 \mathrm{~kg} \cdot \mathrm{d}^{-1}\right)$. Nitrogen intake was higher in the suckler beef system ( $0.54 \mathrm{vs} .0 .44 \mathrm{~kg} \cdot \mathrm{d}^{-1}$ in dairy cows). Nitrogen retention relative to intake in dairy cows and suckler beef was $21.6 \%$ and $6.1 \%$, respectively. Also system energy retention was higher in dairy cows ( $23.1 \%$ of intake) than in suckler beef $(9.2 \%)$. This resulted particularly from a proportionately higher energy expenditure at a similar diet digestibility. The environmentally important excretion of total $\mathrm{N}$, urine $\mathrm{N}$ (both experiments) and methane (experiment II) was higher in suckler beef than in dairy cows. The latter resulted from the difference in fermentable fibre intake. Overall this study suggests a greater efficiency of the dairy system on high-quality grass, although the potential difference in the effort necessary to maintain the respective system was not considered.
\end{abstract}

suckler beef / grass / energy / nitrogen / intake / alkane

* Correspondence and reprints

Tel.: 411632 5972; fax: 411632 1128; e-mail: michael.kreuzer@ inw.agrl.ethz.ch 
Résumé - Comparaison du métabolisme des nutriments et de l'énergie de vaches laitières et de vaches allaitantes alimentées avec de l'herbe à l'auge ou sur un pâturage d'altitude. Deux essais ont été conduits pour déterminer les différences entre l'utilisation de l'herbe (seul aliment) par des vaches laitières $\left(18-20 \mathrm{~kg}\right.$ de lait. $j^{-1}$ ) et par des vaches allaitantes suitées (vaches + veaux $[1,1-1,2 \mathrm{~kg}$ de croît.j $\left.\mathrm{j}^{-1}\right]$ ). Un essai a eu lieu sur un alpage situé à $2000 \mathrm{~m}$ d'altitude, où la quantité de matière sèche ingérée (MSI) et le métabolisme de l'azote $(\mathrm{N})$ ont été étudiés ( $n=5$ par groupe ; essai I). L'autre a eu lieu en plaine (400 m d'altitude), dans une étable équipée de chambres respiratoires permettant, outre l'étude du métabolisme azoté et celle de la MSI, l'étude du métabolisme énergétique ( $n=6$ par groupe, essai II). Dans l'essai II, la précision de l'estimation de l'ingestion permise par l'utilisation de capsules d'alcanes à libération lente a pu être confirmée sur des rations d'herbe. En effet, l'ingestion réelle n'était que $0,19 \mathrm{~kg} \cdot \mathrm{j}^{-1}(1 \%)$ supérieure à l'ingestion estimée avec le rapport d'alcanes $\mathrm{C}_{31}: \mathrm{C}_{32}$. Les meilleures estimations ont été réalisées avec les échantillons fécaux prélevés tôt le matin. Dans l'essai I, l'ingestion de MS et d'N des vaches laitières ne différaient pas de celle des vaches allaitantes seules (respectivement 16 et $0,30 \mathrm{~kg} \cdot \mathrm{j}^{-1}$ ). La rétention d'N était plus élevée chez les vaches laitières que chez les vaches allaitantes (25,7 vs. 9,2\% de l'N ingéré). Dans l'essai II, la MSI des vaches laitières était similaire à celle des vaches allaitantes $\left(16 \mathrm{~kg} \cdot \mathrm{j}^{-1}\right)$, mais la MSI des vaches allaitantes suitées (vaches + veaux) était plus élevée $\left(20 \mathrm{~kg} \cdot \mathrm{j}^{-1}\right)$, tout comme leur ingestion d'N ( 0,54 vs. $0,44 \mathrm{~kg} \cdot j^{-1}$ chez les laitières). La rétention d' $\mathrm{N}$ relative à l'ingestion se montait à $21,6 \%$ et $6,1 \%$ pour les vaches laitières et les vaches allaitantes suitées. De même, la rétention d'énergie était plus élevée chez les vaches laitières $(23,1 \%$ de l'ingestion) que chez les vaches allaitantes suitées $(9,2 \%)$. Cette plus faible rétention était surtout due à une dépense d'énergie accrue, à digestibilité similaire. Les excrétions d'N total, d' $\mathrm{N}$ urinaire (essai I et II), et de méthane (essai II) dans l'environnement étaient plus importantes chez les vaches allaitantes suitées que chez les vaches laitières. Le dernier effet était le résultat d'une ingestion différente de fibres fermentescibles. Ces essais suggèrent donc que des vaches laitières disposant d'herbe de bonne qualité sont plus efficaces que des vaches allaitantes suitées, en prenant en considération que d'éventuelles différences pour maintenir le troupeau ont été négligées.

vaches allaitantes / herbe / énergie / azote / ingestion / alcane

\section{INTRODUCTION}

Suckler beef as a livestock system can utilise marginally profitable areas such as alpine pastures as well as lowland forage resources. This is assumed to be an ecologically and economically sound way of farming resulting in a high-priced meat as the ultimate product. The importance of suckler beef is currently growing whereas simultaneously the number of dairy cows is decreasing due to increasing milk yield at constant milk quota. This provides capacity for alternative livestock systems. The economic sustainability of utilisation of alpine pastures by suckler beef was evaluated by Cayla et al. [7] and the farm benefit by Liénard et al. [26]. Slow-release capsules containing n-alkanes now offer the opportunity to determine herbage and nutrient intake on pasture [3] although information on the accuracy of these capsules in cows and calves on grass-only diets is lacking. On basis of this technique, one study compared early-lactating dairy cows with extensive suckler beef systems on alpine pastures [40], and revealed clear system differences in productivity and nutrient excretion. This might be different using more productive beef breeds, particularly when fed high quality herbage. Additionally, altitude and associated terrain properties as well as botanical composition of the herbage will affect performance and nutrient conversion by the animals [8]. However, for suckler cattle, experimentally derived data on voluntary feed intake and excretion of nutrients, which in excessive amounts may become harmful to 
the environment, are still scarce due to the complicated techniques required to obtain data without separating cow and calf. In a previous study, respiration measurements with suckler beef (cow with calf) were performed and showed dramatically high methane release rates of up to $750 \mathrm{~L} \cdot \mathrm{d}^{-1}$ [13]. That study was performed without a corresponding dairy group. So it is unknown if dairy cows might respond similarly to suckler beef to a grass-only diet typical for low-input systems.

The objective of the present study was to evaluate differences in performance, energy and nitrogen turnover of dairy cows and suckler beef receiving pure grass diets at different altitudes. For this purpose two experiments were conducted, one outside on a high altitude pasture and the other indoors at low altitude including respiration data. The accuracy for grass-only diets of the alkane marker technique with controlled release capsules was determined in dairy cows at low altitude.

\section{MATERIALS AND METHODS}

\subsection{Animals}

Experiment I on high altitude pasture was performed with five multiparous Simmental dairy cows $(2.4 \pm 1.1$ lactations (mean \pm S.D.); $119 \pm 19$ days in lactation) and five multiparous Angus suckler cows (3.8 \pm 2.0 lactations; $281 \pm 14$ days in lactation). Offspring of suckler cows (three males and two females) were Charolais and Limousin sired. Experiment II at low altitude was carried out with six primi- and multiparous Brown Swiss dairy cows $(2.0 \pm 1.3$ lactations) and six multiparous Angus suckler cows $(2.8 \pm 0.8$ lactations $)$ together with their Angus sired calves (three males and three females). At the start of the experiment II, dairy and beef cows were in lactation for $201 \pm 13$ and $202 \pm 17$ days, respectively. Experiments I and II lasted for 19 and $24 \mathrm{~d}$, respectively.

\subsection{Feeding, housing and climatic conditions}

In experiment I animals were pastured on an Alpine grassland located at $2000 \mathrm{~m}$ a.s.l. Dairy cows and suckler beef were kept on two adjacent and similar South-West facing paddocks with moderate inclination varying between 10 and $40 \%$. The herbage offered was highly diverse, consisting of 12 grass species, 8 legume species and 46 herb species. Hand-plucked herbage obtained by imitating the feeding pattern of the cows had a low crude protein, but high dry matter and net energy contents (Tab. I) as is typical for high altitude pastures not treated with mineral fertiliser for a long period of time [8]. During the data and sample collection week, on average the following climatic conditions were measured with an automatic data recording station (Markasub, Basle Switzerland): ambient temperature, $10.5 \pm 2.0{ }^{\circ} \mathrm{C}$; relative air humidity, $74.4 \pm 5.8 \%$; solar radiation, $321 \pm 34 \mathrm{~W} \cdot \mathrm{m}^{-2}$; wind speed, $4.8 \pm 0.6 \mathrm{~m} \cdot \mathrm{s}^{-1}$. There was no precipitation during this period.

Experiment II took place at a lowland site (400 $\mathrm{m}$ a.s.1.) in a cowshed. Cows and calves had ad libitum access to fresh early cut meadow grass (mostly grasses, some red clover) grown at the lowland site. Fibre content and net energy value of this herbage was similar to herbage in experiment I whereas contents of crude protein and duodenally absorbed protein derived from degraded and undegraded feed protein (PDIN) were far higher and dry matter content clearly lower. Herbages also differed in n-alkane contents with generally lower concentrations in the low altitude herbage (Tab. I). $\mathrm{C}_{36}$ contents were not detectable in either herbage. Fresh herbage was provided at $08.00,11.00,15.00$ and $17.30 \mathrm{~h}$. Dairy cows were tethered in stalls equipped for complete collection of faeces and urine. Except during the respiration measurements, suckler beef animals were housed together as one group during the whole experiment in 
Table I. Nutrient and alkane contents of herbage as consumed ( $n=3 / 6$ samples in experiments I/II) and alkane contents of faeces samples $(n=15 / 18$ in experiments I/II) (means \pm S.D.).

\begin{tabular}{|c|c|c|}
\hline & $\begin{array}{l}\text { Alpine grass } \\
\text { (experiment I) }\end{array}$ & $\begin{array}{l}\text { Lowland grass } \\
\text { (experiment II) }\end{array}$ \\
\hline \multicolumn{3}{|l|}{ Herbage composition (per kg DM) } \\
\hline Dry matter (DM, $\mathrm{g} \cdot \mathrm{kg}^{-1}$ wet weight) & $286 \pm 4$ & $127 \pm 9$ \\
\hline Organic matter $(\mathrm{OM}, \mathrm{g})$ & $930 \pm 3$ & $888 \pm 5$ \\
\hline Crude protein $(\mathrm{CP}, \mathrm{g})$ & $120 \pm 2$ & $171 \pm 11$ \\
\hline Crude fibre $(\mathrm{CF}, \mathrm{g})$ & $267 \pm 4$ & $252 \pm 1$ \\
\hline $\operatorname{NDF}(g)$ & -2 & $449 \pm 20$ \\
\hline Gross energy (MJ) & - & $18.2 \pm 0.1$ \\
\hline Net energy lactation (NEL, MJ) ${ }^{1}$ & $5.9 \pm 0.1$ & $5.9 \pm 0.1$ \\
\hline Net energy growth $(\mathrm{NEV}, \mathrm{MJ})^{1}$ & $6.0 \pm 0.1$ & $6.1 \pm 0.1$ \\
\hline Absorbable protein (PDIE, g) ${ }^{1}$ & $93 \pm 0$ & $101 \pm 2$ \\
\hline Absorbable protein (PDIN, g) ${ }^{1}$ & $79 \pm 1$ & $113 \pm 6$ \\
\hline \multicolumn{3}{|l|}{ n-alkane contents ( $\left.m g \cdot \mathrm{kg}^{-1} \mathrm{DM}\right)$} \\
\hline \multicolumn{3}{|l|}{ Herbage } \\
\hline $\mathrm{C}_{31}$ & $244 \pm 6$ & $190 \pm 19$ \\
\hline $\mathrm{C}_{32}^{31}$ & $7 \pm 1$ & $5 \pm 1$ \\
\hline $\mathrm{C}_{33}^{32}$ & $166 \pm 8$ & $42 \pm 6$ \\
\hline \multicolumn{3}{|l|}{ Faeces } \\
\hline $\mathrm{C}_{31}$ & $836 \pm 82$ & $734 \pm 88$ \\
\hline $\mathrm{C}_{32}$ & $362 \pm 93$ & $124 \pm 26$ \\
\hline $\mathrm{C}_{33}$ & $434 \pm 75$ & $159 \pm 27$ \\
\hline $\mathrm{C}_{36}$ & - & $98 \pm 23$ \\
\hline
\end{tabular}

${ }^{1}$ Estimated according to RAP [34]; PDIE = PDI derived from fermentable organic matter and undegradable protein; PDIN = PDI derived from degradable and undegradable protein.

${ }^{2}$ Not determined.

a barn equipped with a slatted floor partly covered with a rubber mat, and straw bedded individual boxes for each calf and each cow. Space allowance was $8.4 \mathrm{~m}^{2}$ per cow with calf, and during daylight animals had access to an outside area of $90 \mathrm{~m}^{2}$. In the cowshed ambient temperature was $19.4 \pm 2.8^{\circ} \mathrm{C}$ and relative air humidity $73.1 \pm 6.0 \%$. Energy balance measurements were made on pairs of animals in turn. For two days each, one dairy cow and one beef cow together with her calf were placed into one of two respiration chambers with a floor size of $2.0 \times 3.6 \mathrm{~m}$ and a volume of $20 \mathrm{~m}^{3}$. During the respiration chamber sojourn beef cows were tethered and calves were kept loose, thus having unlimited access to the mammary gland. The respiration chambers were air conditioned with on average $16.4 \pm 0.3{ }^{\circ} \mathrm{C}$ ambient temperature and $62.4 \pm 4.9 \%$ relative air humidity.

In both experiments the animals had permanent access to fresh water and to a mixture (1:1) of $\mathrm{NaCl}$ and minerals containing per kg: 120 g Ca, $60 \mathrm{~g} \mathrm{P}, 40 \mathrm{~g} \mathrm{Na}, 30 \mathrm{~g} \mathrm{Mg}$, $600000 \mathrm{IU}$ vitamin A, $60000 \mathrm{IU}$ vitamin $\mathrm{D}_{3}$, $1500 \mathrm{IU}$ vitamin E, $500 \mathrm{mg} \mathrm{Cu}, 30 \mathrm{mg} \mathrm{Se}$, $20 \mathrm{mg}$ J, $10 \mathrm{mg}$ Co, according to producer's statement (Kroni AG, Altstätten, Switzerland). Both experiments were conducted in accordance with the Swiss guidelines for animal welfare. 


\subsection{Procedures applied in experiment I}

Experiment I consisted of a main period, with the animals being adapted for $12 \mathrm{~d}$ to the pasture followed by $7 \mathrm{~d}$ of measuring feed intake, performance and $\mathrm{N}$ turnover. Individual faecal excretion, pasture dry matter intake (DMI) and nutrient digestibility of beef cows and calves were determined by the double alkane technique as described by Mayes et al. [31] employing $\mathrm{C}_{31}$ and $\mathrm{C}_{32}$ alkanes as internal and external markers. For this purpose every morning hand-manufactured pellets, produced as described by Mayes et al. [31], of different size for cows and calves were orally introduced for 17 days starting 10 days prior to the beginning of the collection period. Pellets for cows and calves contained $1085 \mathrm{mg}$ and $515 \mathrm{mg}$ of $\mathrm{C}_{32}$ (Koch-Light Ltd., Haverhill, Suffolk), respectively. This technique was used as alkane controlled release capsules (see Sect. 2.4) were not yet available at that time. Spot faeces samples were collected rectally or from fresh dungpats at dawn over the 7 days of the measurement period. Handplucked herbage samples were collected by animal category daily for $12 \mathrm{~h}$ by two people following and mimicking cow and calf selection from one day prior to the start, to one day before the end of faecal sampling, as suggested by Berry et al. [3]. Half of the herbage collected during the sampling period and additional samples taken randomly on the experimental pasture from the standing sward were immediately separated for legume, herb and grass species, dried for $48 \mathrm{~h}$ at $60^{\circ} \mathrm{C}$ and weighed after cooling. Coefficients of selectivity by the animals were computed from the ratios of their proportions in herbage consumed to that in the standing sward. Faeces and herbage samples were frozen upon collection at $-20{ }^{\circ} \mathrm{C}$, defrosted and pooled for each animal or category. Fresh faeces were sub-sampled and refrozen for $\mathrm{N}$ analysis. Herbage and faeces were dried at $60{ }^{\circ} \mathrm{C}$ in a ventilated oven for $48 \mathrm{~h}$. As urine was not collected, body $\mathrm{N}$ retention and, indirectly from that, urine
$\mathrm{N}$ excretion were estimated assuming that all cows and calves had a $\mathrm{N}$ content of $26 \mathrm{~g} \cdot \mathrm{kg}^{-1}$ body weight (BW) change $[1,16]$. The applicability of this constant for BW change was further confirmed by Gibb and Ivings [15], who found nearly the same $\mathrm{N}$ proportion per unit of $\mathrm{BW}$ change in cows gaining or losing $\mathrm{BW}$.

The dairy cows were milked on pasture in a mobile facility, and milk yield was recorded during the collection week at every milking with a spring balance. From four milkings (morning and evening milk, 1:1) during the collection period milk samples were taken and conserved with Bronopol ${ }^{\circledR}$ (BSM2, D \& F Control, San Ramon, USA) for analysis of standard milk constituents. In beef cows, milk yield was estimated by using equations described by RAP [34]. The calculations were based on the estimated intake of metabolisable energy (ME) reduced by the $\mathrm{ME}$ required for maintenance, growth and pregnancy. Energy corrected milk was then estimated by multiplication of the ME remaining for milk synthesis with the coefficient of the efficiency of ME utilisation and by dividing net energy for lactation by 3.14 (cf. also [13]). Body weight was recorded in all animals every third day after morning milking of the dairy cows throughout the experiment. Body weight data for statistical evaluation refer to the average within the 7-d period of collection. In order to obtain sound data for average daily BW change, the BW difference in cows and calves between start and end of the experiment was used, i.e., the variation over the complete 19 -d period of the experiment.

\subsection{Procedures applied in experiment II}

In experiment II the animals were adapted for $14 \mathrm{~d}$ to feeding and housing followed by $8 \mathrm{~d}$ of feed intake measurement and excreta collection, and a 2-d respiration measurement period separating the first from the second $4 \mathrm{~d}$ of the 8 -d collection period. 
Feed intake measurements started one day earlier than faeces collection. One week prior to the start of the collection period, the animals were accustomed to the conditions of the respiration chambers by putting them into the chambers for $1 \mathrm{~d}$. Individual forage intake of dairy and beef cows was monitored using a feeding system equipped with electronic balances (Westfalia Landtechnik, Oelde, Germany) combined with Calan feeding doors (American Calan Inc., Northwood, NH, USA) registering intake at each access. The beef calves also had free access to fresh grass at a separate common feeding place because the computer-controlled troughs did not fit their height. Feed samples were collected every day. Body weight was recorded every second morning before feeding for each animal throughout the experiment, except in the respiration chambers. BW data for statistical evaluation refer to the average within the 10-d period of collection and respiration measurement while daily BW change was calculated from the difference over the complete 24-d period of the experiment.

Milk yield of the dairy cows was recorded for every milking with an automatic system (Westfalia Landtechnik, Oelde, Germany). Milk samples from every milking during the collection week were taken and immediately frozen for later pooling to an aliquot sample of the whole collection week. These samples were stored at $-20{ }^{\circ} \mathrm{C}$ for further analyses. Further milk samples were taken as described for experiment I. In beef cows, milk yield was estimated as in experiment I except that the calculation of ME was performed with energy balance data by subtracting energy loss through faeces, urine and methane from gross energy intake. During the collection week urine of the dairy cows was separated from faeces by urinals fixed on Velcro ${ }^{\circledR}$ tape which were glued onto the clipped skin with instant adhesive (Cyanolit, 3M AG, Rueschlikon, Switzerland). Total faeces of each dairy cow were weighed daily and a homogenous sample was taken and stored at $4{ }^{\circ} \mathrm{C}$. At the end of the collection period aliquot parts of the daily faeces samples were combined, divided into portions and either frozen at $-20{ }^{\circ} \mathrm{C}$ for $\mathrm{N}$ analysis or dried at $60{ }^{\circ} \mathrm{C}$ for $48 \mathrm{~h}$ for further analyses as it was also done with parts of unpooled daily samples. Urine was separated by a collection device placed at the end of the urinal into non-acidified samples (daily frozen at $-20^{\circ} \mathrm{C}$ ) and small samples acidified with $50 \mathrm{ml} 5 \mathrm{M}$ sulphuric acid put into the plastic can before collection. Samples of acidified urine were stored at $4{ }^{\circ} \mathrm{C}$. Daily urine samples were combined proportionately to daily excretion at the end of collection.

Individual faecal excretion and nutrient digestibility of beef cows and calves were estimated by the use of n-alkanes as external markers administered through orally introduced controlled release capsules (CRC, Captec ${ }^{\circledR}$ Ltd. Auckland, New Zealand) and applying the equation of Mayes et al. [31]. Six days prior to the collection period CRC's of type MCM (designed for 300 to $650 \mathrm{~kg}$ body weight) were given to the beef cows and type YC (designed for 100 to $300 \mathrm{~kg}$ body weight) to the calves. During the 8-d collection period individual spot faecal samples were collected in the morning from the first defaecation after rising of the animals. This was identified as the optimum timepoint of the day for this method by Berry et al. [2] and in present study (see results). The double alkane technique as described [2] was also applied to estimate individual grass intake of the calves, employing $\mathrm{C}_{31}$ and $\mathrm{C}_{32}$ alkanes as internal and external markers, respectively.

In order to determine the accuracy of the alkane marker technique based on CRC's under the conditions of a pure fresh herbage, capsules (type MCM) were introduced orally into the rumen of the dairy cows 6 days prior to the collection period (7-10 and 13-16 days after dosing). The collection period approximately fell into the recommended window for sampling (day 8-14 after dosing). The CRC's exude $\mathrm{C}_{32}$ and $\mathrm{C}_{36}$ alkanes at a factory-stated steady release 
rate. For calculation of the mean recovery of alkanes, known intakes of alkanes were related to known excreted alkane amounts over the $8 \mathrm{~d}$ of collection. Fresh herbage and faeces were sampled daily. On day 22 (14 d after dosing CRC's), rectal grabs were taken from all dairy cows at 06.30, 13.30, 17.30 and at $21.30 \mathrm{~h}$ to monitor the withinday variation of alkane excretion as an important component of the accuracy of the spot sampling procedure.

Along with faeces sampling in experiment II, urine was also individually collected from the first urination of the day in beef cows and calves. For beef cows and calves body $\mathrm{N}$ retention and, indirectly from that, total urine $\mathrm{N}$ excretion were estimated as in experiment I. Urine volume was then calculated using estimated excretion and $\mathrm{N}$ concentration analysed in the spot urine samples.

The two respiration chambers designed for cattle and used to quantify gaseous exchange have been described previously [39]. Mean air flow amounting to $38.0 \pm$ $0.2 \mathrm{~m}^{3} \cdot \mathrm{h}^{-1}$ was recorded with in-line electronic flow meters (Swingwirl DV 630; Flowtec AG, Reinach, Switzerland). Outflowing and inflowing air were analysed every 3 and $20 \mathrm{~min}$, respectively. This comprised measurement periods of $20 \mathrm{~s}$ duration each. During these periods, air samples were continously analysed for carbon dioxide and methane by an infrared analyzer (NGA 2000 MLT 1; Fisher Rosemount AG, Baar, Switzerland) and for oxygen by a paramagnetic analyzer (Oxymat 6, Siemens AG, Karlsruhe, Germany), and an average over the $20 \mathrm{~s}$ was computed. The system was manually calibrated directly before and after the respiration measurements as well as automatically every $3 \mathrm{~h}$.

\subsection{Sample analysis}

Dried feed (hand-plucked samples in experiment I) and faeces samples were milled through a $0.75 \mathrm{~mm}$ screen. Contents of dry matter (DM) and organic matter (OM) were analysed by heating samples in an automatic muffle furnace (TGA 500, Leco Instruments, St. Joseph, MI, USA) with steps at $105^{\circ} \mathrm{C}$ and $550{ }^{\circ} \mathrm{C}$ using automatic weight loss measurement until weights remained constant. Crude fibre $(\mathrm{CF})$ and neutral detergent fibre (NDF) contents were determined according to standard techniques $[33,43]$. Contents of gross energy (GE) were measured by anisothermic bomb calorimetry (System C700 T, IKA Analysentechnik $\mathrm{GmbH}$, Heitersheim, Germany). Contents of n-alkanes $\left(\mathrm{C}_{31}, \mathrm{C}_{32}, \mathrm{C}_{33}\right.$ and $\left.\mathrm{C}_{36}\right)$ in feed and faeces were analysed by gas chromatography (HP-6890, Hewlett Packard, Waldbronn, Germany) equipped with a SPB-1 column (Supelco, Buchs, Switzerland) by duplicate extraction using direct saponification [2]. Carbon and nitrogen contents of feed, non-dried faeces, urine and milk were assessed by an automatic C/N analyser (Leco-Analyzer Type FP-2000, Leco Instruments, St. Joseph, MI, USA). The Bronopol ${ }^{\circledR}$ conserved milk samples were analysed for fat, protein and lactose with infrared technique (Milkoscan 4000, Foss Electric, Hillerød, Denmark). The energy excretion with urine was calculated from the equation proposed by Hoffmann and Klein [22]. Contents of net energy for lactation (NEL), net energy for growth (NEV) and duodenally absorbed protein either from undegradable protein and energy (PDIE) or from undegradable and degradable protein (PDIN) in herbage were calculated from nutrient analyses according equations given by RAP [34]. Energy expenditure (heat energy release) of the animals was computed from gaseous exchange data and urine $\mathrm{N}$ excretion according to convention by the equation of Brouwer [6]. As gaseous exchange data were inseparably combined for beef cows and calves they could be only treated together as a cow-calf pair. Body energy retention in the beef cow-calf system was calculated from system GE input less energy losses through faeces, urine, methane and heat. 


\subsection{Statistical evaluation}

All statistical analyses were performed with SAS [36]. The procedures applied in experiments I and II in order to determine nutrient turnover provided individual data on dairy and beef cows, on calves and on suckler cow-calf pairs. A general linear model (GLM) procedure was applied for analysis of variance. Effects of animal category (dairy cows, beef cows, beef calves) or, in a separate analysis, of livestock system (dairy system vs. suckler system) $(\alpha)$ was tested in both experiments by the following model:

$$
\text { Model 1: } y_{i j}=\mu+\alpha_{j}+e_{i j}
$$

where $y_{\mathrm{ij}}$ represents the value of individual $i$ issued from the jth category/system $(\alpha)$. In a preliminary analysis, gender of the calves had neither a significant influence on intake nor on excretion of nutrients of beef cows together with calves, and therefore was not included in the final analysis. Multiple comparisons among animal categories were performed with the Tukey procedure, provided category effect was significant. $P$-values $<0.05$ were considered significant.

In experiment II data on variation of alkane concentration in daily herbage and faecal samples, alkane recovery, known and estimated intake were subjected to a mixed model (Model 2; method = REML). Data obtained from six dairy cows on eight sampling days ( $n=48$ observations) were analysed with sampling day $(\beta)$ as fixed effect. The covariation within animals $\mathrm{V}\left(\mathrm{d}_{\mathrm{jk}}\right)$ was accounted for in an analysis of repeated measures, and the optimal covariance structure for all data sets was found to be compound symmetric $\left(\operatorname{cov}\left(\mathrm{e}_{\mathrm{jk}}\right)\right)$ with attention to Schwarz's Bayesian criterion as explained by Littell et al. [27].

Model 2: $y_{j k l}=\mu+\beta_{j}+V\left(d_{j k}\right)+\operatorname{cov}\left(e_{j k l}\right)$

where $y_{j k l}$ represents the value of individual 1 issued from the $j$ th sampling day $(\beta)$.

\section{RESULTS}

\subsection{Alkane intake and excretion and estimates of grass intake from alkanes}

In both experiments of the present study, n-alkanes were used to estimate feed intake and digestibility. Concentrations of $\mathrm{C}_{31}, \mathrm{C}_{32}$ and $\mathrm{C}_{33}$ alkanes in herbage and faeces were generally higher in experiment I than in experiment II (Tab. I). Herbage contents of $\mathrm{C}_{32}$ were low and $\mathrm{C}_{36}$ was not detected at all. Therefore faecal excretion of these alkanes mostly resulted from the dosed alkanes (no $\mathrm{C}_{36}$ dosed in experiment I). The accuracy of estimation of known DMI from different alkane ratios in experiment II (Tab. II) was high with $\mathrm{C}_{31}: \mathrm{C}_{32}$ (underestimated by $1 \%$ ) and slightly lower with $\mathrm{C}_{33}: \mathrm{C}_{32}$ (deviation of $3 \%$ ). The calculated alkane recovery rates were quite similarly high for all alkanes analysed ranging between 0.87 and 0.90. Sampling day had no significant effect, either on DMI estimations or on alkane recoveries. Spot faeces sampling matched known intake best when performed at 06.30 h using the $\mathrm{C}_{31}: \mathrm{C}_{32}$ ratio. In the case of the $\mathrm{C}_{33}: \mathrm{C}_{32}$ ratio the optimal sampling time for intake estimation was $17.30 \mathrm{~h}$, followed by $06.30 \mathrm{~h}$.

\subsection{Experiment I}

Grass DMI of dairy cows was similar to that of beef cows together with their calves (Tab. III). Related to the body weight, DMI was lower $(P<0.01)$ in the suckler beef system than in dairy cows by more than $25 \%$. On the botanically highly diverse alpine pasture, all animal categories selected for grasses and against legumes and herbs which had made up respective proportions of 45,25 and $30 \%$ of total biomass DM in the standing sward. In the dairy cows, coefficients of selectivity were $1.51,0.47$ and 0.75 in grasses, legumes and herbs (data not given in table). The respective values were 1.39, 
Table II. Comparison of known to estimated herbage intake and recovery rates of n-alkanes in dairy cows (experiment II) ${ }^{1}$.

\begin{tabular}{|c|c|c|c|}
\hline & Means \pm S.D. & $\begin{array}{l}\text { Difference } \\
\text { from known } \\
\text { intake }\end{array}$ & $\begin{array}{c}P \text {-value } \\
\text { Day effect }{ }^{2}\end{array}$ \\
\hline \multicolumn{4}{|l|}{ Herbage intake $\left(\mathrm{kg} \mathrm{DM} \cdot \mathrm{d}^{-1}\right)^{3}$} \\
\hline Known intake & $16.00 \pm 2.96$ & & 0.386 \\
\hline $\begin{array}{l}\text { Intake estimated by alkane ratios } \\
\qquad \mathrm{C}_{31}: \mathrm{C}_{32}\left(\mathrm{~kg} \mathrm{DM} \cdot \mathrm{d}^{-1}\right) \\
\mathrm{C}_{33}: \mathrm{C}_{32}\left(\mathrm{~kg} \mathrm{DM} \cdot \mathrm{d}^{-1}\right)\end{array}$ & $\begin{array}{l}15.81 \pm 3.73 \\
15.58 \pm 3.46\end{array}$ & $\begin{array}{l}-0.19 \\
-0.42\end{array}$ & $\begin{array}{l}0.626 \\
0.619\end{array}$ \\
\hline $\begin{array}{l}\text { Recovery of alkanes (mean) } \\
\mathrm{C}_{31} \text { (faecal output/intake) } \\
\mathrm{C}_{32} \text { (faecal output/intake \& stated release) } \\
\mathrm{C}_{33} \text { (faecal output/intake) } \\
\mathrm{C}_{36}(\text { faecal output/stated release })\end{array}$ & $\begin{array}{l}0.888 \pm 0.175 \\
0.904 \pm 0.164 \\
0.882 \pm 0.181 \\
0.867 \pm 0.141\end{array}$ & & $\begin{array}{l}0.401 \\
0.681 \\
0.465 \\
0.832\end{array}$ \\
\hline $\begin{array}{l}\text { Effect of time on sampling estimates on day } 21 \\
\text { Known intake (kg DM) } \\
\text { Intake estimated by alkane ratios from grab } \\
\text { samples taken at }\end{array}$ & $16.11 \pm 3.72$ & & \\
\hline $\begin{array}{rr}\mathrm{C}_{31}: \mathrm{C}_{32} & 06.30 \mathrm{~h} \\
13.30 \mathrm{~h} \\
17.30 \mathrm{~h} \\
21.30 \mathrm{~h}\end{array}$ & $\begin{array}{l}16.09 \pm 3.90 \\
15.92 \pm 3.96 \\
15.38 \pm 3.21 \\
14.28 \pm 2.10\end{array}$ & $\begin{array}{l}-0.02 \\
-0.19 \\
-0.73 \\
-1.83\end{array}$ & \\
\hline $\begin{array}{r}\mathrm{C}_{33}: \mathrm{C}_{32} \\
06.30 \mathrm{~h} \\
13.30 \mathrm{~h} \\
17.30 \mathrm{~h} \\
21.30 \mathrm{~h}\end{array}$ & $\begin{array}{l}15.77 \pm 3.56 \\
16.56 \pm 4.86 \\
15.91 \pm 4.24 \\
14.85 \pm 2.75\end{array}$ & $\begin{array}{r}-0.34 \\
0.45 \\
-0.20 \\
-1.26\end{array}$ & \\
\hline
\end{tabular}

\footnotetext{
${ }^{1}$ Values from six dairy cows with eight sampling days each.

2 Probability of error of significant between-day variation (variance analysis by Model 2).

${ }^{3}$ Day 6-9 and day 12-15 after dosing, i.e. day 14-17 and day 20-23 of the experiment.
}

0.54 and 0.71 for the beef cows and 1.47 , 0.33 and 0.85 for their calves. Digestibility of OM was similar in dairy and beef cows. This item could not be measured in the calves because of the unknown level of milk intake from their dams. Beef cows were found to digest crude fibre better than their calves and the dairy cows. The dairy cows were heavier than the beef cows by $66 \mathrm{~kg}$ on average, and lost weight during their alpine sojourn whereas beef cows slightly gained weight. The milk yield of the dairy cows was almost twice that estimated in the beef cows. Dairy cow milk on average contained $3.74 \%$ fat, $3.09 \%$ protein, and $4.90 \%$ lactose.

System $\mathrm{N}$ input and faecal $\mathrm{N}$ excretion were similar in the dairy cow and the suckler beef system (75\% of total herbage $\mathrm{N}$ intake by the beef cows), whereas urinary $\mathrm{N}$ excretion was estimated to be higher $(P<0.01)$ in suckler beef by $43 \%$ (Tab. IV). This also resulted in a higher total manure $\mathrm{N}$ amount $(+21 \% ; P<0.05)$ and a higher urinary $\mathrm{N}$ proportion of manure $\mathrm{N}(+18 \%$; $P<0.1$ ). System retention (body $\mathrm{N}$ and milk N) in the dairy cows exceeded the level 
Table III. Intake and digestibility of herbage ${ }^{1}$ and performance of dairy cows and beef cows with calves in experiment I (Alpine grass on pasture; $\mathrm{n}$ by group $=5$ ) and in experiment II (meadow grass indoors; $n$ by group $=6$ ) (means \pm S.D.).

\begin{tabular}{lccccccc}
\hline & $\begin{array}{c}\text { Dairy } \\
\text { cows }\end{array}$ & $\begin{array}{c}\text { Beef } \\
\text { cows }\end{array}$ & $\begin{array}{c}\text { Beef } \\
\text { calves }\end{array}$ & $\begin{array}{c}\text { Beef } \\
\text { system }\end{array}$ & S.E.D. & & $P$-value \\
\cline { 3 - 8 } & & & & & & System Category \\
\hline Experiment I & & & & & & & \\
DM intake $\left(\mathrm{kg} \cdot \mathrm{d}^{-1}\right)$ & $15.8^{\mathrm{a}} \pm 2.0$ & $11.6^{\mathrm{b}} \pm 1.5$ & $3.9^{\mathrm{c}} \pm 0.4$ & 15.6 & 0.78 & 0.865 & 0.001 \\
DM intake $(\%$ of BW) & $2.6^{\mathrm{a}} \pm 0.3$ & $2.2^{\mathrm{a}} \pm 0.3$ & $1.4^{\mathrm{b}} \pm 0.2$ & 1.9 & 0.12 & 0.003 & 0.001 \\
OM digestibility (\%) & $75.2 \pm 1.4$ & $76.3 \pm 1.9$ & & & & & 0.324 \\
CF digestibility $(\%)$ & $71.9^{\mathrm{b}} \pm 0.9$ & $76.0^{\mathrm{a}} \pm 2.6$ & $71.0^{\mathrm{b}} \pm 3.0$ & 74.7 & 0.77 & 0.030 & 0.013 \\
Body weight $(\mathrm{kg})$ & $602^{\mathrm{a}} \pm 52$ & $536^{\mathrm{a}} \pm 75$ & $282^{\mathrm{b}} \pm 30$ & 818 & 31.7 & 0.002 & 0.001 \\
Weight change $\left(\mathrm{g} \cdot \mathrm{d}^{-1}\right)$ & $-289^{\mathrm{b}} \pm 684$ & $100^{\mathrm{b}} \pm 182$ & $989^{\mathrm{a}} \pm 382$ & 1089 & 255.5 & 0.005 & 0.003 \\
Milk yield $\left(\mathrm{kg} \cdot \mathrm{d}^{-1}\right)^{3}$ & $17.5^{\mathrm{a}} \pm 1.2$ & $9.3^{\mathrm{b}} \pm 2.8$ & & & & & 0.001 \\
& & & & & & & \\
Experiment II & & & & & & & \\
DM intake $\left(\mathrm{kg} \cdot \mathrm{d}^{-1}\right)$ & $16.1^{\mathrm{a}} \pm 2.1$ & $16.2^{\mathrm{a}} \pm 1.9$ & $3.7^{\mathrm{b}} \pm 0.8$ & 19.9 & 0.95 & 0.019 & 0.001 \\
DM intake $(\%$ of BW) & $2.8^{\mathrm{a}} \pm 0.3$ & $2.6^{\mathrm{a}} \pm 0.3$ & $1.5^{\mathrm{b}} \pm 0.1$ & 2.3 & 0.10 & 0.002 & 0.001 \\
OM digestibility $(\%)$ & $77.5 \pm 2.0$ & $75.6 \pm 2.3$ & & & & & 0.341 \\
CF digestibility $(\%)$ & $73.5 \pm 2.0$ & $72.9 \pm 4.3$ & $76.3 \pm 4.0$ & 73.6 & 1.24 & 0.967 & 0.237 \\
NDF digestibility $(\%)$ & $72.9 \pm 2.8$ & $69.4 \pm 6.9$ & $74.9 \pm 3.6$ & 70.4 & 1.88 & 0.377 & 0.161 \\
Body weight $(\mathrm{BW}, \mathrm{kg})$ & $569^{\mathrm{a}} \pm 51$ & $631^{\mathrm{a}} \pm 46$ & $241^{\mathrm{b}} \pm 47$ & 872 & 26.8 & 0.001 & 0.001 \\
Weight change $\left(\mathrm{g} \cdot \mathrm{d}^{-1}\right)$ & $-241^{\mathrm{c}} \pm 198$ & $55^{\mathrm{b}} \pm 83$ & $1205^{\mathrm{a}} \pm 102$ & 1260 & 75.7 & 0.001 & 0.001 \\
Milk yield $\left(\mathrm{kg} \cdot \mathrm{d}^{-1}\right)^{3}$ & $19.5^{\mathrm{a}} \pm 4.6$ & $8.3^{\mathrm{b}} \pm 3.8$ & & & & & 0.001 \\
\hline
\end{tabular}

a-c Means of dairy cows, beef cows and beef calves lacking a common superscript differ at $P<0.05$.

${ }^{1}$ All estimates based on the $\mathrm{C}_{31}: \mathrm{C}_{32}$ alkane ratio and early-morning faecal samples.

${ }^{2}$ Standard error of difference between dairy and beef system.

${ }^{3}$ Estimates for suckler cows (see Materials and methods).

found in suckler beef, and therefore system $\mathrm{N}$ utilisation (retention:intake) was 2.8 -fold higher $(P<0.001)$ in the dairy cows $(25.7$ vs. $9.2 \%)$.

\subsection{Experiment II}

Dairy cows consumed less grass DM indoors at low altitude in experiment II than beef cows together with their calves whereas DMI of dairy and beef cows was similar. Related to body weight, DMI in the suckler system was lower $(P<0.01)$ than in the dairy system. Digestibilities of OM and fibre (crude fibre, NDF) were not significantly different between animal categories and systems. Beef cows exceeded dairy cows in weight by $62 \mathrm{~kg}$ but produced less than half of the milk of the corresponding dairy cow group. Milk of the dairy cows contained $4.23 \%$ fat, $3.39 \%$ protein, and $4.70 \%$ lactose. Dairy cows lost weight and beef cows slightly gained weight. Calves had high daily gains of more than $1.2 \mathrm{~kg} \cdot \mathrm{d}^{-1}$.

System $\mathrm{N}$ input was clearly higher in suckler beef $(P<0.05)$ than in the dairy cows with the proportion of total herbage $\mathrm{N}$ input consumed by the calves accounting for $19 \%$ of total beef $\mathrm{N}$ input. Both faecal and urinary $\mathrm{N}$ excretion were higher in the beef system than in dairy cows, but no greater differences were measured between systems in urine $\mathrm{N}$ percentage of total manure N. System N retention in dairy cows 
Table IV. Nitrogen turnover of dairy cows and beef cows with calves in experiment I (Alpine grass on pasture; $n$ by group $=5$ ) and in experiment II (meadow grass indoors; $n$ by group $=6)($ means and S.E.D.).

\begin{tabular}{|c|c|c|c|c|c|c|c|c|}
\hline \multirow[b]{2}{*}{ System } & \multicolumn{4}{|c|}{ Experiment I } & \multicolumn{4}{|c|}{ Experiment II } \\
\hline & Dairy & Beef & S.E.D. & $P$-value & Dairy & Beef & S.E.D. & $P$-value \\
\hline \multicolumn{9}{|l|}{$N$ balance $\left(g \cdot d^{-1}\right)$} \\
\hline $\mathrm{N}$ intake (from herbage) & 301 & 303 & 15.1 & 0.945 & 441 & 544 & 28.7 & 0.030 \\
\hline Faecal N & 108 & 106 & 9.4 & 0.902 & 104 & 150 & 5.7 & 0.001 \\
\hline Urinary $\mathrm{N}^{1}$ & 116 & 166 & 10.2 & 0.008 & 238 & 361 & 13.7 & 0.006 \\
\hline Milk N & 85 & & & & 103 & & & \\
\hline Body $\mathrm{N}$ retention ${ }^{1}$ & -8 & 28 & 6.6 & 0.005 & -4 & 33 & 23.7 & 0.016 \\
\hline System $\mathrm{N}$ retention & 77 & 28 & 7.8 & 0.002 & 99 & 33 & 25.8 & 0.006 \\
\hline $\begin{array}{l}\text { Relative system } N \text { retention } \\
\quad(\% \text { of } \mathrm{N} \text { intake })\end{array}$ & 25.7 & 9.2 & 2.24 & 0.001 & 21.6 & 6.1 & 4.42 & 0.004 \\
\hline \multicolumn{9}{|l|}{ Manure $N$} \\
\hline Total manure $\mathrm{N}\left(\mathrm{g} \cdot \mathrm{d}^{-1}\right)$ & 224 & 272 & 12.5 & 0.025 & 342 & 511 & 16.1 & 0.001 \\
\hline Urine $\mathrm{N}\left(\mathrm{g} \cdot \mathrm{kg}^{-1}\right.$ total $\left.\mathrm{N}\right)$ & 516 & 609 & 30.1 & 0.081 & 694 & 670 & 14.1 & 0.842 \\
\hline
\end{tabular}

${ }^{1}$ Body $\mathrm{N}$ retention and urinary $\mathrm{N}$ excretion (calculated indirectly from $\mathrm{N}$ intake, faecal $\mathrm{N}$ excretion and $\mathrm{N}$ retention) estimated assuming $26 \mathrm{~g} \mathrm{~N} \cdot \mathrm{kg}^{-1}$ body weight change $[1,16]$, except for dairy cows in experiment II (direct measurement of urine $\mathrm{N}$ excretion).

was three times the level found in suckler beef. This and the higher $\mathrm{N}$ input increased the difference in $\mathrm{N}$ utilisation between dairy cows and suckler beef to 3.5-fold.

Gross energy intake (GEI) from herbage was equal in dairy and beef cows (292 vs. $293 \mathrm{MJ} \cdot \mathrm{d}^{-1}$ ), with the calves consuming an additional $68 \mathrm{MJ} \cdot \mathrm{d}^{-1}$ (Tab. V). System energy excretion via faeces, urine, methane and heat was generally higher in the suckler beef system than in the dairy cows $(P<0.01)$, even relative to GEI. Accordingly, energy loss through faeces, urine, methane and heat made up 27.7, 5.6, 5.8 and $37.9 \%$ of GEI in the dairy system and $30.0,7.3,6.5$ and $46.9 \%$ in the suckler system (significant for urine and heat energy proportion). System emission of methane was, however, not significantly different when related to intake of NDF and digested NDF. On average methane levels were $63 \pm$ $7 \mathrm{~L} \cdot \mathrm{kg}^{-1} \mathrm{NDF}$ and $88 \pm 5 \mathrm{~L} \cdot \mathrm{kg}^{-1}$ digested
NDF. With the dairy cows, system energy retention was about twice the rate of the suckler system $(P<0.01)$, thus clearly differing in gross energy utilisation (23.1 vs. $9.2 \%)$.

\section{DISCUSSION}

As far as known, this study for the first time directly compared similarly fed beef cows with calves and dairy cows in their whole body energy and nutrient turnover. The cow-calf system was kept together during the experiment to maintain behavioural interactions of cow and calf. As a consequence, several indirect approved approaches such as the alkane technique had to be applied. Due to compounding of errors, this reduced the accuracy of the data, particularly for beef cattle and for urine-related traits which were calculated indirectly from $\mathrm{N}$ balance. 
Table V. Energy turnover of dairy cows and suckler cows with calves in experiment II (meadow grass indoors; $n$ by group $=6$ ) (means and S.E.D.).

\begin{tabular}{lccrr}
\hline & Dairy cow system & Suckler beef system & S.E.D. & $P$-value \\
\hline Energy balance $\left(M^{\prime} \cdot d^{-1}\right)$ & & & & \\
$\quad$ Gross energy intake (herbage) & 292 & 361 & 17.4 & 0.019 \\
Faecal energy & 81 & 108 & 4.8 & 0.003 \\
$\quad$ Urinary energy & 16 & 27 & 1.1 & 0.002 \\
Methane energy & 17 & 23 & 1.1 & 0.003 \\
Energy expenditure & 110 & 168 & 5.5 & 0.001 \\
Milk energy & 63 & 35 & 10.2 & 0.047 \\
$\quad$ Body energy retention & 5 & 35 & 9.5 & 0.023 \\
$\quad$ System energy retention & 68 & & & \\
Relative energy retention & & 9.2 & 2.40 & 0.002 \\
$\quad$ System (\% of gross energy intake) & 23.1 & & & \\
\hline
\end{tabular}

${ }^{1}$ Estimates based on the procedures outlined in the footnote of Table IV (suckler beef) and the equation of Hofmann and Klein [22].

\subsection{The accuracy of the $\mathrm{CRC}$ alkane technique in cows fed exclusively grass}

Techniques to apply alkanes as external markers in order to estimate faeces excretion and herbage intake are described for daily application in Mayes et al. [31] and for single application via controlled release capsules (CRC's) in Berry et al. [2]. Both methods rely on the steady ratio of faecal excretion of dosed $\mathrm{C}_{32}$ alkane (and $\mathrm{C}_{36}$ with CRC's) to $\mathrm{C}_{31}$ and $\mathrm{C}_{33}$ originating from the plants consumed. The high alkane concentration of alpine herbage presumably was a result of the high percentage of legumes and herbs compared to the low altitude herbage $[12,28]$. In the present study both alkane techniques were applied and both yielded reasonable and comparable figures for intake and digestibility. However, the manufacture and application of the hand-made alkane pellets as used in experiment I was very time-consuming.

The accuracy of the CRC technique has been already extensively tested, but only with silage diets [2], high concentrate diets [21] or forage diets with high DM content [10]. A separate test with grass-only diets was therefore considered important as forage type affects ruminal nutrient turnover and digesta flow rate and so may influence alkane release from CRC's and/or homogeneity of faecal excretion of alkanes. The results of this CRC test, performed within experiment II and following the principles outlined by Berry et al. [2], confirmed its applicability, particularly when based on early-morning faecal samples [in line with 2, 19] and on the $\mathrm{C}_{31}: \mathrm{C}_{32}$ ratio. Berry et al. [2] noted a slightly higher accuracy with the $\mathrm{C}_{33}: \mathrm{C}_{32}$ ratio, but subsequently variability between cows was found to be higher than with the $\mathrm{C}_{31}: \mathrm{C}_{32}$ ratio [3], as was also true for the present investigation. Furthermore, as in other studies [24, 29], the $C_{33}$ alkane content of lowland grass was lower than $50 \mathrm{mg} \cdot \mathrm{kg}^{-1}$ considered as threshold value for the use of n-alkanes as marker. Finally, the optimum day time for sampling was less clear with $\mathrm{C}_{33}: \mathrm{C}_{32}$ than with $\mathrm{C}_{31}: \mathrm{C}_{32}$ (Tab. II), but no reason was obvious for this difference. Although sampling exceeded the recommended 8-d sampling window for CRC's, this period remained within the expected time-span of steady release rate [2] and the lack of significant day effects on intake estimates and alkane recovery rate 
suggests that this extension was justifiable. Alkane recovery rates were higher than described in Herd et al. [21] and Berry et al. [2], and did not systematically vary with chain length as also found earlier [11]. As there was a slight difference in recovery rate between $\mathrm{C}_{31}$ and $\mathrm{C}_{32}$, a corresponding adjustment for intake calculation was applied [2].

\subsection{Feed intake and nutrient and energy supply from grass-only diets}

Diets consisting exclusively of grass, as used in this study, are common for suckler beef feeding whereas dairy cows typically receive a certain amount of additional concentrate, except on high altitude pasture where supplementary feeding often cannot be practised and is of low efficiency to sustain a high level of performance $[3,5]$. Therefore, system comparisons are difficult to achieve on the basis of literature data, as the basic system effects cannot be separated from the diet effects. In the present study, an extensive system comparison of fast-growing beef vs. medium yielding dairy cows, typically exposed to low-concentrate rations, was performed on the basis of the same feed. These are two major livestock system options to utilise forage of the quality available at low and at high altitude. This study supplements a previous one comparing extremes on the same alpine pasture, namely early-lactating cows and a slow-growing beef breed [40], which were either underfed (dairy) or poorly utilising the feed resources (beef).

As expected from the lower level of performance, the average herbage DMI of $16 \mathrm{~kg} \cdot \mathrm{d}^{-1}$ (dairy cows) was slightly lower than that found previously in early-lactating dairy cows on the same high-altitude pasture $[3,8]$. As beef cows had a clearly lower estimated milk yield, their lower intake compared to the dairy cows is reasonable. Compared to results found by Marshall et al. [30] in beef cows with calves grazing a grass-legume pasture, intake level was higher in the present study, but not higher than that of Scottish Highland beef cows at high altitude [40]. In contrast, beef cows at low altitude (experiment II) seem to have consumed nutrients from grass in excess although it has to be noted that these beef cows were heavier than the dairy cows whereas the opposite was true for experiment I. Body weight change and body $\mathrm{N}$ retention data, but not body energy retention data (maybe as a consequence of some estimates that had to be made), illustrate that dairy cows were still mobilising body reserves at both locations whereas beef cows were able to gain weight. This is another indication for the assumption that nutrients were slightly in excess for the beef cows. Calf weight gains were $20 \%$ higher on lowland than on high altitude pasture, where similar daily weight gains were found as with Angus and Angus $\times$ Simmental suckler calves kept on the same site [14].

In agreement with the findings of Gruber and Steinwender [17] as well as of Leach et al. [25] obtained with dairy cows, the present results suggest that the type of grass offered at low altitude was sufficient in terms of energy supply to achieve a high performance (milk yield and daily weight gain), whereas at high altitude the extra demand to cope with low oxygen pressure, unfavourable slopes and other constraints $[4,8,9]$ was not covered by extra herbage intake of the calves or of the dams, as can seen from the even higher DMI (in \% of $\mathrm{BW}$ ) on low altitude. In this context, demands of terrain, herbage quality and the possibility to select from botanically diverse alpine pastures [18] are of high importance, and interactions among these factors may also influence feed intake of different animal categories. Cattle are basically able to select for feed of a high digestibility and energy content [8], which might partly explain the preference for alpine grasses observed which can be assumed to have had lower contents of undigestible fibre compared to legumes and herbs [37]. However, part of this specific 
selection pattern might also have resulted from the fact that, in the standing sward, grasses had a greater average height than legumes and herbs. Apart from that, the possibility cannot be excluded that calves in experiment I had a lower genetically limited growth potential because this high altitude pasture proved to be more than sufficient to express maximum growth yield in slow maturing breeds [40]. Further studies, carried out with varying slopes, expositions and herbage diversity, which allow to separate these factors, might assist to make decisions on the optimum category and breed grazed on these pastures.

\subsection{System differences in efficiency on grass diets}

System energy demand was lower in the suckler beef systems than in dairy cows of moderate milk yield (18-20 kg), as shown by their lower voluntary intake of grass per $\mathrm{kg} \mathrm{BW}$. Typically, in suckler systems the proportion of energy supply required for maintenance purpose is as high as $75 \%$ of total demand [38]. The high importance of maintenance is confirmed by the higher proportion of gross energy lost as heat energy (energy expenditure) in the suckler system compared to the dairy system. Even the energetic efficiency of the dairy cows was at the lower end of the range described [39], although the efficiency of utilisation of metabolisable energy for milk production $\left(\mathrm{k}_{\mathrm{L}}=0.59 \pm 0.08\right.$; calculated according to [42]) ranged at the level expected for dairy cows $[34,42]$.

Nitrogen intake presumably was not a key issue for intake regulation since intake was similar or lower on the low-protein grass (experiment I). Therefore, $\mathrm{N}$ utilisation was not only dependent on the livestock system but also on herbage $\mathrm{N}$ content. Declining $N$ utilisation to unfavourably low levels was also found for suckler beef grazing re-growth of higher $\mathrm{N}$ content on alpine pasture [14]. Independently, system differences in $\mathrm{N}$ utilisation were high presumably due to the inevitable two-fold transformation loss (feed to milk to meat) in the suckler system. This difference was further increased by the lower level of productivity (milk yield of the beef cows) thus increasing the proportion of $\mathrm{N}$ to be attributed to maintenance requirements. System differences in relative $\mathrm{N}$ retention were similar in both experiments indicating that effects of herbage $\mathrm{N}$ content and system were additive. Comparing early-lactating dairy cows with extensive beef breeds on alpine pasture with herbage of higher $\mathrm{N}$ content, Sutter et al. [40] found a lower system $N$ utilisation than in the present study, but the differences between animal category nevertheless were in the same range. The system differences described in the present investigation should well reflect also the differences occurring on an annual basis as milk yields of dairy cows were typical for average lactation and beef calves had about the average weight with respect to complete fattening. The dry period, a particularly unproductive phase, is also characterised by a lower feed and $\mathrm{N}$ intake which should widely compensate. For dairy cows with approx. $6000 \mathrm{~kg}$ milk per year, the annual manure $\mathrm{N}$ amount would then account for 80 to $125 \mathrm{~kg}$ whereas the respective value in beef (cow with calf) would be range between 100 and $190 \mathrm{~kg}$ per year, depending on dietary crude protein excess. On a hectare basis, system differences get slightly lower when beef cattle is consuming more feed than dairy cows as was the case in experiment I on alpine pasture.

\subsection{System differences in nitrogen and methane emissions}

In both experiments, i.e. at similar and at different grass $\mathrm{N}$ intake, total manure $\mathrm{N}$ amount and the excretion of the easilyvolatile urine $\mathrm{N}$ were significantly higher in the suckler beef system compared to the dairy system, and in experiment I the 
urine- $\mathrm{N}$ proportion of total $\mathrm{N}$ was also higher. This can be explained by the relatively low $\mathrm{N}$ demand of the beef cows for milk synthesis and by the contribution of the calves to a high urine $\mathrm{N}$ proportion resulting from the ingestion of the highly digestible milk N. Overall, system differences were lower than differences resulting from the $42 \%$ higher grass $\mathrm{N}$ content in experiment II compared to experiment I. Excessive $\mathrm{N}$ is completely excreted, mainly in the form of urine $\mathrm{N}$, thus clearly increasing potential ammonia emissions during storage and application of manure. Accordingly, Kröber et al. [23] found a 3.5-fold increase in gaseous $\mathrm{N}$ loss from dairy manure when dietary crude protein content of a forage-concentrate diet (1:1) was increased from 125 to $175 \mathrm{~g} \cdot \mathrm{kg}^{-1} \mathrm{DN}$, values similar to the herbage types used in experiments I and II. Consequently, a low $\mathrm{N}$ content of grass, as was analysed in experiment $\mathrm{I}$, is fully sufficient for efficient suckler beef production and any $\mathrm{N}$ fertilisation will increase $\mathrm{N}$ emission potential. Even in dairy cows a low-protein grass seems to be sufficient as is also suggested [23] by the similar fibre digestibility in both experiments.

Methane release found in dairy cows was only slightly lower than that reported for early-lactating dairy cows of a far higher milk yield and DMI [20, 39]. This can be explained by the use of a forage-only diet with a high fibre digestibility as methane is predominantly formed from fermentable fibre. Accordingly, methane release relative to NDF intake did not significantly differ between systems. The methane level of $63 \mathrm{~L} \cdot \mathrm{kg}^{-1} \mathrm{NDF}$ was equal to the one found in forage-fed Simmental and Angus beef cows with calves [13], and similar to the levels of $67 \mathrm{~L} \cdot \mathrm{kg}^{-1}$ reported by Reynolds and Tyrrell [35] for beef cows separated from their calves, and of $59 \mathrm{~L} \cdot \mathrm{kg}^{-1}$ (data corrected by $10 \%$ additional methane from hindgut [41]) found with $\mathrm{SF}_{6}$ tracer gas technique in pastured beef cattle by McCaughey et al. [32]. This illustrates that methane emissions from dairy cow and suckler beef systems mostly depend on differences in feed intake as well as utilisation and result in a very high methane release per unit of edible protein (assuming that $100 \%$ of milk protein and $60 \%$ of body protein retention $(\mathrm{N} \times 6.25)$ of the calves are edible $)$ in the suckler system $(5.13 \pm 0.44$ vs. $0.67 \pm$ $0.13 \mathrm{~L} \cdot \mathrm{g}^{-1}$ in dairy cows). Also Yan et al. [44] noted no differences in methane emission per unit of feed intake between dairy cattle and beef steers when animals of both categories were fed grass silage-based diets. For both, the dairy and the suckler beef system, a similar annual methane emission per hectare can be estimated from the present data accounting for $4 \times 10^{5} \mathrm{~L}$ on a low altitude site (2.5 livestock units with $600 \mathrm{~kg} \cdot \mathrm{ha}^{-1}$; winter feeding assumed to cause the same methane release) and one tenth of that level on a high altitude pasture (typically 1 livestock unit during 3 months of vegetation).

\section{CONCLUSIONS}

Although in both experiments suckler beef calves had relatively high daily gains compared to the range typically found on forage-only systems, the efficiency of the suckler system was clearly inferior to that of the dairy system even in this low-input system offering only grass. This was associated with a higher excretion of non-utilised nutrients and methane which might be environmentally harmful. The suckler system appears particularly inefficient when the nutrient inputs are related to the amount of edible nutrients produced. This is mainly due to the lower utilisation of nutrients for meat than for milk synthesis and, additionally the nutrient loss occurring during twofold transformation of nutrients and energy from feed to cow to calf. It has to be kept in mind that this comparison neglects potential differences which may occur in the nutrient losses needed to maintain the respective systems. Considering the current trend to abandon dairy systems in favour of suckler 
systems in less favoured areas, further studies on the requirements of suckler beef on pasture are needed in order to define the minimum $\mathrm{N}$ and energy contents, and thus increase the efficiency of the system.

\section{ACKNOWLEDGEMENTS}

We are grateful to Dr. H. Leuenberger, C. Welter, N. Schellenberg, A. Fliri and A. Felder for their assistance in organising and performing the experiments at the ETH research stations Chamau and Weissenstein. We are also grateful to H. Bossi, C. Kunz and E. Lupberger for support in the laboratory and M. Steiger Burgos for preparation of the French summary. This study was performed within the polyproject PRIMALP (Sustainable Primary Production in the Alpine Region) of ETH Zurich.

\section{REFERENCES}

[1] Anderson P.T., Bergen W.G., Merkel R.A., Hawkins D.R., The effects of dietary crude protein level on the rate, efficiency and composition of gain of growing bulls, J. Anim. Sci. 66 (1988) 1990-1996.

[2] Berry N.R., Scheeder M.R.L., Sutter F., Kröber T.F., Kreuzer M., The accuracy of intake estimation based on the use of alkane controlledrelease capsules and faeces grab sampling in cows, Ann. Zootech. 49 (2000) 3-13.

[3] Berry N.R., Sutter F., Bruckmaier R., Blum J., Kreuzer M., Limitiations of high-alpine grazing conditions for early-lactation cows: effects of energy and protein supplementation, Anim. Sci. 73 (2001) 149-162.

[4] Bianca W., Hays F.L., Vergleichende Untersuchungen am Rind bei Stallhaltung im Tal und auf der Alp sowie bei Weidehaltung auf der Alp, Schweiz. Landw. Forsch. 16 (1977) 215-234.

[5] Bovolenta S., Ventura W., Piasentier E., Malossini F., Supplementation of dairy cows grazing an alpine pasture: Effect of concentrate level on milk production, body condition and rennet coagulation properties, Ann. Zootech. 47 (1998) 169-178.

[6] Brouwer E., Report of sub-committee on constants and factors, in: Blaxter K.L. (Ed.), Energy Metabolism of Farm Animals, EAAP Publ No. 11, Academic Press, London-New York, 1965, pp. 441-443.

[7] Cayla R., Bouchy B., Liénard G., Place des estives dans les systèmes allaintants Salers, Ann. Zootech. 47 (1998) 445-451.
[8] Christen R.E., Kunz P.L., Langhans W. Leuenberger H., Sutter F., Kreuzer M., Productivity, requirements and efficiency of feed and nitrogen utilization of grass-fed early lactating cows exposed to high Alpine conditions, J. Anim. Physiol. Anim. Nutr. 76 (1996) 22-35.

[9] Coulon J.B., Pradel P., Effect of walking on roughage intake and milk yield and composition of Montbéliarde and Tarentaise dairy cows, Ann. Zootech. 46 (1997) 139-146.

[10] Dicker R.W., Herd R.M., Oddy V.H., Alkanes and controlled release devices for estimating intake of ryegrass by cattle, Proc. Nutr. Soc. Aust. (1996) 107.

[11] Dove H., Mayes R.W., The use of plant wax alkanes as marker substances in studies of nutrition of herbivores: a review, Aust. J. Agric. Res. 42 (1991) 913-952.

[12] Dove H., Mayes R.W., Plant wax components: a new approach to estimating intake and diet composition in herbivores, J. Nutr. 126 (1996) 13-26.

[13] Estermann B.L., Sutter F., Schlegel P.O., Erdin D., Wettsstein H.-R., Kreuzer M., Effect of calf age and dam breed on intake, energy expenditure and excretion of nitrogen, phosphorus and methane of beef cows with calves, J. Anim. Sci. (2002) in press

[14] Estermann B.L., Wettstein H.-R., Erdin D. Sutter F., Kreuzer M., Herbage intake and nitrogen turnover of suckler cows of different breeds and their calves on subalpine and alpine pastures, Proc. Soc. Nutr. Physiol. 10 (2001) 130.

[15] Gibb M.J., Ivings W.E., A note on the estimation of the body fat, protein and energy content of lactating Holstein-Friesian cows by measurement of condition score and live weight, Anim Prod. 56 (1993) 281-283.

[16] Gibb M.J., Ivings W.E., Dhanoa M.S., Sutton J.D., Changes in body components of autumncalving Holstein-Friesian cows over the first 29 weeks of lactation, Anim. Prod. 55 (1992) 339-360.

[17] Gruber L., Steinwender R., Influence of forage quality on digestibility, feed intake and milk yield of dairy cows, in: Parente G., Frame J., Orsi S. (Eds.), Grassland and Land Use System, European Grassland Federation, Grado, Italy, 1996, pp. 437-440.

[18] Gruber L., Steinwidder A., Stefanon B., Steiner B., Steinwender R., Influence of grassland management in Alpine regions and concentrate level on $\mathrm{N}$ excretion and milk yield of dairy cows, Livest. Prod. Sci. 61 (1999) 155-170.

[19] Hameleers A., Mayes R.W., The use of n-alkanes to estimate herbage intake and diet composition by dairy cows offered a perennial ryegrass/white clover mixture, Grass Forage Sci. 53 (1998) 164-169. 
[20] Hattan A.J., Beever D.E., Cammell S.B., Sutton J.D., Energy metabolism in high yielding dairy cows during early lactation, in: Chwalibog A., Jakobsen K. (Eds.), Energy Metabolism of Farm Animals, EAAP Publ. 103, Wageningen Pers, The Netherlands, 2001, pp. 325-328.

[21] Herd R.M., Williams T.M.J., Woodgate R., Ellis K.J., Oddy V.H., Using alkane technology to measure intake of a barley diet by cattle, Proc. Nutr. Soc. Aust. (1996) 106.

[22] Hofmann L., Klein M., Die Abhängigkeit der Harnenergie vom Kohlenstoff- und Stickstoffgehalt im Harn bei Rindern, Schafen, Schweinen und Ratten, Arch. Tierernähr. 30 (1980) 743-750.

[23] Kröber T.F., Külling D.R., Menzi H., Sutter F., Kreuzer M., Quantitative effects of feed protein reduction and methionine on nitrogen use by cows and nitrogen emission from slurry, J. Dairy Sci. 83 (2000) 2941-2951.

[24] Laredo M.A., Simpson G.D., Minson D.J., Orpin C.J., The potential for using n-alkanes in tropical forages as a marker for the determination of dry matter intake by grazing ruminants, J. Agric. Sci. Camb. 117 (1991) 355-361.

[25] Leach K.A., Bax J.A., Efficiency of nitrogen use in dairy systems, Accounting for nutrients: a challenge for grassland farmers in the $21 \mathrm{~s}$ century, in: Corrall A.J. (Ed.), Proc. Brit. Grassl Soc. Conf., Malvern, UK, 1999, pp. 69-74.

[26] Liénard G., Lherm M., Bébin D., Effets de la réforme de la PAC et des incitations à l'extensification sur le fonctionnement des exploitations allaitantes charolaises, Ann. Zootech. 47 (1998) 431-443.

[27] Littell R.C., Henry P.R., Ammerman C.B. Statistical analysis of repeated measures data using SAS procedures, J. Anim. Sci. 76 (1998) 1216-1231.

[28] Malossini F., Bovolenta S., Piasentier E., Valentionatti M., Variability of n-alkanes content in a natural pasture and in faeces of grazing dairy cows, Anim. Feed Sci. Technol. 50 (1994) 113-122.

[29] Malossini F., Bovolenta S., Piasentier E., Piras C., Martillotti F., Comparison of n-alkanes and chromium oxide methods for estimating herbage intake by grazing dairy cows, Anim. Feed Sci. Technol. 61 (1996) 155-165.

[30] Marshall S.A., Campbell C.P., Buchanan-Smith J.G., Herbage biomass and intake of beef cows with calves grazing a grass-legume pasture in southern Ontario, Can. J. Anim. Sci. 78 (1998) 211-218.

[31] Mayes R.W., Lamb C.S., Colgrove P.M., The use of dosed and herbage n-alkanes as markers for the determination of herbage intake, J. Agric Sci. Camb. 107 (1986) 161-170.
[32] McCaughey W.P., Wittenberg K., Corrigan D., Impact of pasture type on methane production by lactating beef cows, Can. J. Anim. Sci. 79 (1999) 221-226.

[33] Naumann K., Bassler R., Die chemische Untersuchung von Futtermitteln, Methodenbuch Vol. 3, VdLUFA-Verlag, Darmstadt, Germany, 1997.

[34] RAP, Swiss Federal Research Station for Anima Production, Fütterungsempfehlungen und Nährwerttabellen für Wiederkäuer, 4th ed., Landwirtschaftliche Lehrmittelzentrale, Zollikofen, Switzerland, 1999.

[35] Reynolds C.K., Tyrrell H.F., Energy metabolism in lactating beef heifers, J. Anim. Sci. 78 (2000) 2696-2705.

[36] SAS, SAS/STAT Software Release 6.12, SAS Inst. Inc., Cary, NC, USA, 1996.

[37] Schubiger F.X., Bosshard H.R., Dietl W., Nährwert von Alpweidepflanzen, Agrarforsch. 5 (1998) 285-288.

[38] Sinclair K.D., Agabriel J., The adaptation of domestic ruminants to environmental constraints under extensive conditions, Ann. Zootech. 47 (1998) 347-358.

[39] Sutter F., Beever D.E., Energy and nitrogen metabolism in Holstein-Friesian cows during early lactation, Anim. Sci. 70 (2000) 503-514.

[40] Sutter F., Berry N.R., Jewell P., Edwards P.J., Kreuzer M., Performance and nitrogen turnover of suckler beef and dairy cows on well managed high-mountainous pasture as compared with beef on a previously abandoned pasture, in: Gagnaux D., Poffet J.R. (Eds.), Livestock Farming Systems. Integrating Animal Science Advances into the Research for Sustainability, EAAP Publ. 97, Wageningen Pers., The Netherlands, 2000, pp. 201-203.

[41] Torrent J., Johnson D.E., Methane production in the large intestine of sheep, in: Aguilera J.F. (Ed.), Energy Metabolism of Farm Animals, CSIC Publishing Service, Granada, Spain, 1994, pp. 391-394.

[42] Van Es A.J.H., van der Honing Y., Energy utilisation, in: Broster B.H., Swan H. (Eds.), Feeding strategy for the high yielding dairy cow, Granada Publishing Limited, London/Toronto/ Sydney/New York, 1978, pp. 68-89.

[43] Van Soest P.J., Robertson J.B., Lewis B.A. Methods for dietary fiber, neutral detergent fiber, and nonstarch polysaccharides in relation to animal nutrition, J. Dairy Sci. 74 (1991) 3583-3597.

[44] Yan T., Agnew R.E., Gordon F.J., Porter M.G. Prediction of methane energy output in dairy and beef cattle offered grass silage-based diets, Livest. Prod. Sci. 64 (2000) 253-263. 